Article

\title{
Nutritional Peak Week and Competition Day Strategies of Competitive Natural Bodybuilders
}

\author{
Andrew J. Chappell *(D) and Trevor N. Simper \\ Food and Nutrition Group, Sheffield School of Business, Sheffield Hallam University, \\ Howard St., Sheffield S1 1WB, UK; t.simper@shu.ac.uk \\ * Correspondence: a.chappell@shu.ac.uk; Tel.: +44-114-225-3336
}

Received: 21 September 2018; Accepted: 22 October 2018; Published: 24 October 2018

check for updates

\begin{abstract}
Bodybuilders utilize peaking strategies in a bid to fine-tune their aesthetics for competition day. The most prevalent peaking strategies utilized by natural bodybuilders are unreported in the current literature. Eighty-one (M-59, F-22) natural bodybuilders were recruited from competitions during the 2016 and 2017 British Natural Bodybuilder Federation seasons. Competitors completed a 34-item questionnaire designed to investigate peaking and contest day strategies. The questionnaire listed commonly utilized peaking strategies and provided additional space for qualitative information. Analysis of the data indicated that carbohydrate $(\mathrm{CHO})$, water, and sodium manipulation were the most commonly utilized peaking strategies. The consumption of high glycemic index CHO was the most common competition day strategy. Only $6.2 \%$ of competitors reported following their regular diet the week prior to competition. The $\mathrm{CHO}$ manipulation strategies followed were similar to classical $\mathrm{CHO}$ loading, whereby bodybuilders attempt to maximize muscle glycogen concentrations. Furthermore, bodybuilders attempted to remove superfluous water by exploiting the diuretic/polyuria effect associated with water loading/restriction. The potentially deleterious effects of peaking on bodybuilders' health is considered and the efficacy of these strategies to enhance appearance is discussed. The findings of the present investigation are likely to be of interest to bodybuilders and their coaches.
\end{abstract}

Keywords: bodybuilding; drug free; competing; peaking; carbohydrate loading; water loading; sodium loading; fat loading; Vitamin C; fibre restriction

\section{Introduction}

In competitive bodybuilding, athletes are judged on muscle size, conditioning (appearance of low body fat), and symmetry (muscular proportions) [1]. To obtain the desired physique, bodybuilders employ strict dietary and training regimes, in the months prior to competition [2-5]. In the week prior to competition, bodybuilders also employ tapering strategies for "fine-tuning the body" in an attempt to maximize their contest day aesthetics [6-8]. Known as "peaking" or "peak week", these strategies involve the manipulation of macronutrients, electrolytes, water, and exercise $[6,8,9]$. The main goals of peaking are: (1) To increase "muscle fullness", by maximizing muscle glycogen content; (2) to obtain a "dry" or "hard" look, by minimizing subcutaneous water; and, (3) finally, maximizing the "V-taper", by minimizing abdominal bloating $[6,8,10-12]$.

There is a lack of scientific literature published on the peaking strategies of competitive bodybuilders. Only a single trial to date has investigated the effects of carbohydrate loading (CHOL) on muscle girth, finding no effect [9]. This study replicated the popular "Aceto/Addison" peaking method, however, it was performed on a non-bodybuilding population under isocalorfic conditions [9,11]. Despite these findings, CHOL is popular amongst bodybuilding populations [8]. Peaking for success, however, is known to be challenging and stressful, while poorly conceived strategies can be detrimental 
to performance [8]. Peaking strategies are often self-prescribed or designed by coaches, the safety of which has been called into question [13]. This point is emphasized by the fact a recent study reported that only $14.1 \%$ of bodybuilding coaches were qualified nutritionists/dietitians [1,14]. Moreover, a qualitative study of bodybuilders reported that athletes felt there was a lack of scientific nutritional knowledge amongst coaches [8]. Therefore, observing the peaking strategies used by competitive bodybuilders, as well as discussing their potential mechanisms of action would be of value to the bodybuilding community. This cross-sectional investigation aims to detail and describe peaking strategies, and is likely to be of interest to bodybuilders and coaches seeking to improve their understanding of the pre-competition phase.

\section{Materials and Methods}

\subsection{Experimental Approach to the Problem}

Male and female competitors participating in the British Natural Bodybuilding Federation (BNBF) championship qualifiers in 2017 submitted data, which was then combined with a previous dataset from the 2016 BNBF British championship [3]. All competitors were subject to the same drug testing and polygraphing criteria explained previously [3]. Drug testing was carried out on all class winners at regional qualifiers, alongside targeted testing in accordance with the World Anti-Doping Agency prohibited list $[15,16]$. Recruitment was performed by the first author (AC) as described previously [3]. All participants were informed of the study aims and methods via a participant information sheet, and those agreeing to take part provided written informed consent. Each participant then completed a 34-item questionnaire (see Supplementary Material S1), that inquired about dietary and training habits, weight change, and peak week and competition day strategies. The questionnaire provided a list of commonly utilised peaking strategies, as well as space for participants to provide additional qualitative information on those strategies. Qualitative quotes were counted and grouped based on the peaking strategies they related to and representative quotes are provided for context. Participants provided varying amounts of qualitative data; some competitors provided detailed accounts of strategies utilised, while others provided short statements. Qualitative quotes are presented verbatim. Missing questionnaire data and clarification of strategies were followed up via email. The most commonly followed peaking strategies were counted, and are presented as a percentage of the total population. This investigation was approved by the Sheffield Hallam University School of Business Ethics Committee. Ethics application number SBS-191, approved 19 September 2016.

\subsection{Participants}

Eighty-two participants were recruited for the present investigation. One competitor was excluded after failing a pre-competition polygraph test. The final data set included 81 competitive natural bodybuilders ( $n=59$ male, $n=22$ female). Participant characteristics are detailed in Table 1 . Competitors provided their self-reported weight prior to starting their contest diet and their weight the day prior to competition. Total weight loss, the difference in weight loss, and body mass index (BMI) $\left(\mathrm{kg} / \mathrm{m}^{2}\right)$ was calculated with self-reported height. The male data set was comprised entirely of bodybuilders from the following classes: Teens $(n=4)$, under 23 years $(n=8)$, novices $(n=10)$, open weight $(n=20)$, masters $(n=13)$, and professional $(n=5)$. All female competitors were also grouped together and were recruited from the following classes: Figure $(n=15)$ open $(n=9)$, over 40 years $(n=4)$, professional figure $(n=2)$, athletic $(n=5)$, and bodybuilding $(n=3)$. It is worth noting that figure and athletic classes place less emphasis on muscle size compared to bodybuilding, body fat levels are distinctly different between athletic (lower) and figure (where it is higher). 
Table 1. Characteristics of British competitive natural bodybuilders.

\begin{tabular}{lcccc}
\hline & Males $\boldsymbol{n} \mathbf{5 9}$ & \multicolumn{3}{c}{ Females $\boldsymbol{n - 2 2}$} \\
\cline { 2 - 5 } & Mean & \pm & Mean & \pm \\
\hline Age & 33.02 & 12.00 & 34.74 & 9.70 \\
Years Training & 12.48 & 9.49 & 5.29 & 6.16 \\
Years Competing & 3.56 & 3.14 & 2.30 & 1.26 \\
Diet Length (weeks) & 22.68 & 9.45 & 23.65 & 6.91 \\
Height (m) & 1.77 & 0.06 & 1.63 & 0.05 \\
Diet Start Weight (kg) & 88.32 & 10.14 & 63.82 & 6.72 \\
Diet End Weight (kg) & 76.57 & 78.10 & 55.20 & 5.22 \\
Total Weight Loss (kg) & 11.73 & 5.55 & 8.62 & 3.40 \\
Weight Loss Per Week (kg) & 0.63 & 0.55 & 0.39 & 0.16 \\
\% Weight Loss & 13.00 & 5.55 & 13.31 & 4.48 \\
\% Weight Loss Per Week & 0.72 & 0.66 & 0.60 & 0.24 \\
End BMI (kg/m ${ }^{2}$ ) & 24.55 & 1.79 & 20.63 & 1.27 \\
\hline
\end{tabular}

Abbreviations: \pm standard deviation, $\mathrm{m}=$ meters, $\mathrm{kg}=$ kilogram, $\%$ = percentage, $\mathrm{BMI}=$ body mass index.

\section{Results}

\subsection{Peak Week Strategies}

The strategies utilised during peak week are detailed in Table 2. Of the 81 competitors surveyed, only $5(6.2 \%)$ reported following their 'regular diet' in the week prior to competition (i.e., they did not employ a specific peaking strategy). Peaking strategies were not always mutually exclusive, and competitors employed multiple strategies sometimes simultaneously e.g., CHO restriction combined with loading.

Carbohydrate manipulation was the most common peaking strategy; qualitative quotes indicated that restriction and loading lasted between one and four days, with restriction preceding loading (Table 3). Carbohydrate intake during the restriction phase varied and competitors reported consuming between 0 and $100 \mathrm{~g}$ per day. Conversely, CHO intake during loading was reported to be over $2500 \mathrm{~g}$ or $833 \mathrm{~g}$ per day (11.1 g/ kg bodyweight (BW) in a $75 \mathrm{~kg}$ bodybuilder) amongst three male competitors. Bodybuilders reported consuming white and sweet potatoes, oats, confectionary, white rice, grapes, and bananas during CHOL. Water manipulation was the most popular strategy after CHO manipulation. The amount of water consumed during the loading phase varied between 4 to $12 \mathrm{~L}$ per day (53.3 to $160 \mathrm{~mL} / \mathrm{kg}$ BW in a $75 \mathrm{~kg}$ bodybuilder) (Table 3). Water loading preceded restriction, with competitors reducing their water intake as they approached the competition. Ten to $24 \mathrm{~h}$ prior to competition, competitors reported employing water restriction strategies. Competitors also loaded and restricted sodium in the days prior to competition. Qualitative quotes indicated that sodium manipulation was practiced three to four days prior to competition (Table 3). Quotes indicated that there was no consistent order for sodium loading/restriction strategies, i.e., some competitors restricted prior to loading and others vice versa. Finally, competitors reported megadosing with vitamin C (VITC) (1 to $8 \mathrm{~g}$ per day) in the days preceding competition. Other strategies employed included protein and fat loading as well as the use of dandelion tea. A graphical representation of a common peaking plan is provided in Figure 1 for reference purposes. 
Table 2. Prevalence of peak week strategies amongst British competitive natural bodybuilders.

\begin{tabular}{|c|c|c|c|c|c|c|c|c|c|c|c|c|}
\hline & \multicolumn{3}{|c|}{ Carbohydrate } & \multicolumn{3}{|c|}{ Water } & \multicolumn{3}{|c|}{ Sodium } & \multirow[b]{2}{*}{ Vit. C } & \multirow[b]{2}{*}{ Reg. Diet } & \multirow[b]{2}{*}{ 'Other' } \\
\hline & Restriction & Loading & Both * & Loading & Restriction & Both * & Restriction & Loading & Both * & & & \\
\hline \multirow{2}{*}{ Males n-59 } & 34 & 46 & 28 & 38 & 16 & 12 & 9 & 13 & 4 & 14 & 5 & 5 \\
\hline & $57.6 \%$ & $78.0 \%$ & $47.4 \%$ & $64.4 \%$ & $27.1 \%$ & $20.3 \%$ & $15.3 \%$ & $22.0 \%$ & $6.8 \%$ & $23.7 \%$ & $8.5 \%$ & $8.5 \%$ \\
\hline \multirow{2}{*}{ Females n-22 } & 18 & 21 & 17 & 15 & 10 & 8 & 2 & 2 & 1 & 5 & 0 & 0 \\
\hline & $81.8 \%$ & $95.5 \%$ & $77.3 \%$ & $68.2 \%$ & $45.5 \%$ & $36.4 \%$ & $9.1 \%$ & $9.1 \%$ & $4.5 \%$ & $22.7 \%$ & $0.0 \%$ & $0.0 \%$ \\
\hline \multirow{2}{*}{ Total n-81 } & 52 & 67 & 45 & 53 & 26 & 20 & 11 & 15 & 5 & 19 & 5 & 5 \\
\hline & $64.2 \%$ & $82.7 \%$ & $55.0 \%$ & $65.4 \%$ & $32.1 \%$ & $25.0 \%$ & $13.6 \%$ & $18.5 \%$ & $6.2 \%$ & $23.5 \%$ & $6.2 \%$ & $6.2 \%$ \\
\hline
\end{tabular}

Results are expressed as total counts and percentages. Abbreviations, Vit $C=$ vitamin $C$ loading is practiced, Reg. Diet $=$ regular competition diet is followed. 'Other' examples include, protein and fat loading, and large amounts of dandelion tea consumption. * represents the number and percentage of competitors who employed both restriction and loading. Note the columns above represent the order in which loading and restriction are practiced, i.e., water loading typicaly preceeds water restriction.

Table 3. Indicative quotes about peak week strategies from British competitive natural bodybuilders.

\begin{tabular}{|c|c|c|}
\hline Peek Week Strategy & Counts of Qualitative Text & Indicative Quotes \\
\hline Carbohydrate Restriction & 54 & $\begin{array}{l}\text { "At the start of peak week I would switch back to low carbs until } 3 \text { days out", "I gradually increase my water load the week before contest day } \\
\text { and also carb deplete in that week, for around } 3 \text { days, depends on my looks and the final } 2 \text { days before I carb load, being } 2.5 \text { times more than my } \\
\text { normal carb intake", "Three day deplete, high fibre and protein", "Deplete } 3 \text { days ... carbs } 100>75>60 \mathrm{~g} \text { ", " } 4 \text { day carb deplete", "3 days, } \\
1 / 2 \text { carbs every day", }\end{array}$ \\
\hline Carbohydrate Loading & 64 & $\begin{array}{l}\text { "Carb loaded } 2 \text { days before using high GI (glycemic index) carb + rice. Increased water on these days", " } 4 \text { days out a mix of simple and } \\
\text { complex carbs, } 1100 \mathrm{~g}, 600 \mathrm{~g}, 400 \mathrm{~g}, 700 \mathrm{~g} \text { ", "three day load, high GI initially followed by low GI } 2500 \mathrm{~g} \text { over } 3 \text { days", Load } 3 \text { days ... . carbs } \\
1200,800,500 \mathrm{~g} \text { ", "Carb and water load } 3 \text { x maintenance level", "Carb up slowly for } 3 \text { days using sweet potatoes, rice cakes, jam" }\end{array}$ \\
\hline Water Loading & 42 & $\begin{array}{l}\text { "I water load on peak week while increasing vitamin C, then drop water back down", " } 1 \text { day } 12 \mathrm{~L} \text { and then lower at } 8 \mathrm{~L} \text { then } 4 \text { L", "10 L for } 7 \\
\text { day out", "Water } 8 \text { L day, stop consuming } 10 \text { p.m. evening before show", "up to } 8 \mathrm{~L} \text { Thurs, } 7 \mathrm{~L} \text { Fri, taper off Saturday" }\end{array}$ \\
\hline Water Restriction & 26 & $\begin{array}{l}\text { "Cut water } 24 \text { h from show just sip", "the day before cut water out", "Stop water a } 3 \text { p.m. day before show-glass of wine night before and sip } \\
\text { an wine day of show", "Water reduction from Friday (Sunday competition)", "Cutting water around } 6 \text { p.m. (night before competition)", } \\
\text { "Night before show I cut water, sipping with carb meals only" }\end{array}$ \\
\hline Sodium Depleting & 10 & $\begin{array}{l}\text { "Salt gradually reduced last } 3 \text { days below } 1 \mathrm{~g} \text { Na/day", "Stopped salt } 3 \text { days before comp.", "No salt the last } 3 \text { days", "No salt all during the } \\
\text { week" }\end{array}$ \\
\hline Sodium Loading & 16 & $\begin{array}{l}\text { "Salting meals-pink salt all week", "Increased sodium for } 4 \text { days", "salt high till day before then lower water + drop salt", "On contest day I } \\
\text { load up with salt (sodium)", "relative to CHO + water" }\end{array}$ \\
\hline Vitamin C Loading & 17 & $\begin{array}{l}\text { " } 4 \text { days out } 2 g, 3 \text { days out } 4 g, 2 \text { days out } 6 g, 1 \text { day out } 8 g \text { ", "Throughout days } 2 \text { and } 3 \text {, vitamin } C \text { and water loading over ... two days } \\
\text { before show vit } C \text { increases accordingly", "Increase water ... 1:1 ratio of } 1000 \mathrm{mg} \text { of vit } C \text {, then drop water to } \frac{1}{2} \text { day before keeping vit } C \text { at } \\
5000 \mathrm{mg} \text { ", "up to } 2000 \mathrm{mg} \text { daily } 4 \text { days pre comp" }\end{array}$ \\
\hline Regular Diet is Followed & 5 & $\begin{array}{l}\text { "No I believe in sticking to my diet plan right until the end, its never led me wrong, but I would be open to trying other things on show day", } \\
\text { "No, we didn't change much", "No major changes to overall routine" }\end{array}$ \\
\hline
\end{tabular}




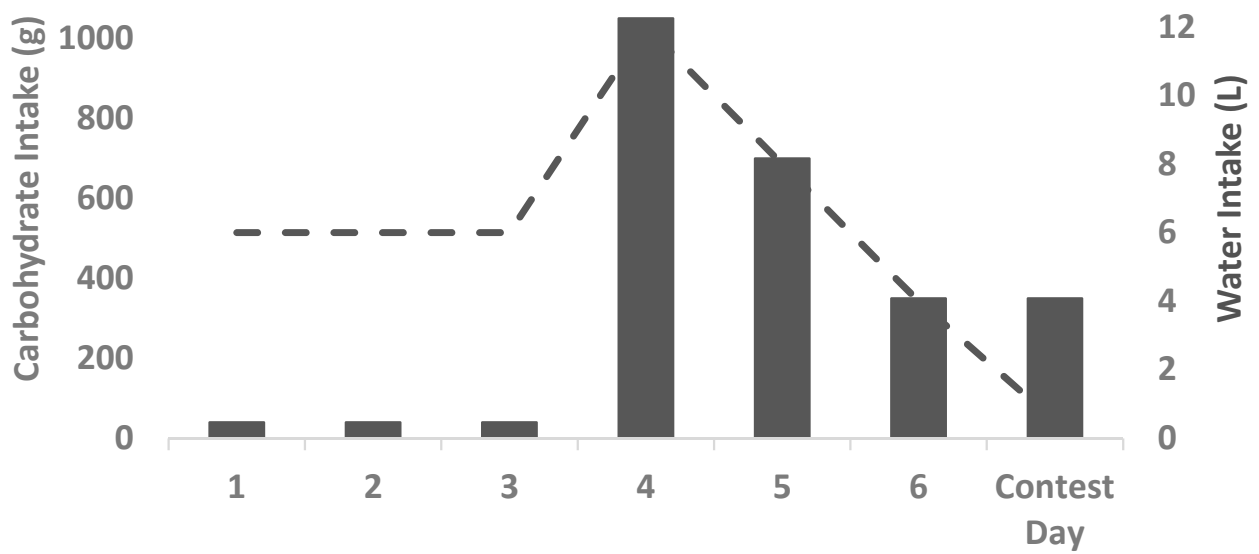

Day

Carbohydrate (g) - Water (L)

Figure 1. The Aceto/addision peak week. A proposed peaking plan based on an $80 \mathrm{~kg}$ bodybuilder with a daily carbohydrate $(\mathrm{CHO})$ intake of $350 \mathrm{~g}$ per day $(4.4 \mathrm{~g} / \mathrm{kg} \mathrm{BW})$. Three days of $\mathrm{CHO}$ restriction (40 g per day, days 1 to 3 ) is employed, followed by two days of loading. High intensity aerobics and high volume resistance training is employed during the $\mathrm{CHO}$ restriction phase to deplete muscle glycogen stores. During the $\mathrm{CHO}$ loading phase, the regular dietary $\mathrm{CHO}$ intake is multiplied by three $(1050 \mathrm{~g}, 13.2 \mathrm{~g} / \mathrm{kg} \mathrm{BW})$ and two $(750 \mathrm{~g}, 9.4 \mathrm{~g} / \mathrm{kg}$ BW) on days 4 and 5, respectively. Intake on day 6 (day prior to competition) returns to the regular dietary intake $(350 \mathrm{~g}(4.4 \mathrm{~g} / \mathrm{kg} \mathrm{BW})$ and coincides with water restriction. The total $\mathrm{CHO}$ intake over this three day period is $2150 \mathrm{~g}$. The majority of $\mathrm{CHO}$ consumed on competition day are consumed pre-stage. Water intake parallels CHO intake, peaking on day 4, before water restriction is imposed 12 to $16 \mathrm{~h}$ prior to competing. Water may be completely restricted or reduced to sipping on contest day. Finally, sodium manipulation and vitamin $C$ loading may be introduced on days 5, 6, and contest day. Abbreviations: $\mathrm{CHO}=$ carbohydrate, $\mathrm{BW}=$ bodyweight.

\subsection{Competition Day Strategies}

Twenty-one male (35.6\%) and 4 female (18.2\%) competitors reported following their regular diet on competition day, although many of these competitors employed one specific additional strategy of extra $\mathrm{CHO}$ intake pre-stage. Details of competition day strategies and commonly consumed contest day foods are provided in Tables 4-6.

The consumption of high glycaemic index (GI) CHO prior to stepping on stage was the most widely used contest day strategy. Fruit, confectionary, and preserves were the competitors preferred choice of $\mathrm{CHO}$ during the pre-stage period (Table 5). A high $\mathrm{CHO}$ intake persisted from peak week and competitors reported consuming rice cakes, white and sweet potatoes, oats, and rice on competition day (Table 5). Water restriction also continued from peak weak, with competitors reporting minimal or restricted intake on contest day (Table 6). A low fibre diet via the exclusion of fibrous vegetables was the most common strategy after $\mathrm{CHO}$ and water manipulation. Alcohol and sodium loading prior to competing was also reported and competitors opted for spirits or wines and salty snacks, and/or adding salt to meals. High protein and fat strategies involved competitors grazing on foods high in protein and fat or where competitors opted for high protein and fat breakfasts (Table 6). Other contest day strategies included water loading, the consumption of B-vitamin supplements, the use of arginine based supplements, and the restriction of both $\mathrm{CHO}$ and food to reduce bloating. 
Table 4. Prevalence of competition day strategies amongst British competitive natural bodybuilders.

\begin{tabular}{|c|c|c|c|c|c|c|c|c|}
\hline & High GI CHO. Pre Stage & Higher CHO. & Water Restriction & Minimal Fibre & Alcohol & High Protein/Fat Grazing & Sodium Loading & ‘Other' \\
\hline Male n-59 & $\begin{array}{c}40 \\
67.8 \%\end{array}$ & $\begin{array}{c}27 \\
45.8 \%\end{array}$ & $\begin{array}{c}12 \\
20.3 \%\end{array}$ & $\begin{array}{c}11 \\
18.6 \%\end{array}$ & $\begin{array}{c}9 \\
15.3 \%\end{array}$ & $\begin{array}{c}5 \\
8.5 \%\end{array}$ & $\begin{array}{c}9 \\
15.3 \%\end{array}$ & $\begin{array}{c}8 \\
13.6 \%\end{array}$ \\
\hline Females $n-22$ & $\begin{array}{c}16 \\
81.8 \%\end{array}$ & $\begin{array}{c}5 \\
22.7 \%\end{array}$ & $\begin{array}{c}6 \\
27.3 \%\end{array}$ & $\begin{array}{c}5 \\
22.7 \%\end{array}$ & $\begin{array}{c}6 \\
27.3 \%\end{array}$ & $\begin{array}{c}3 \\
13.6 \%\end{array}$ & $\begin{array}{c}2 \\
9.1 \%\end{array}$ & $\begin{array}{c}3 \\
13.6 \%\end{array}$ \\
\hline Total n-81 & $\begin{array}{c}59 \\
71.6 \%\end{array}$ & $\begin{array}{c}32 \\
39.5 \%\end{array}$ & $\begin{array}{c}18 \\
22.2 \%\end{array}$ & $\begin{array}{c}16 \\
19.8 \%\end{array}$ & $\begin{array}{c}16 \\
18.5 \%\end{array}$ & $\begin{array}{c}8 \\
9.9 \%\end{array}$ & $\begin{array}{c}11 \\
13.6 \%\end{array}$ & $\begin{array}{c}11 \\
13.6 \%\end{array}$ \\
\hline
\end{tabular}

'Other' strategies include: Water loading, the consumption of B-vitamins, the use of arginine based supplements, CHO restriction, and food restriction. Abbreviations: GI = Glycaemic Index, $\mathrm{CHO}=$ carbohydrate.

Table 5. Foods consumed by British competitive natural bodybuilders on competition day.

\begin{tabular}{ll}
\hline High Glycaemic Index Carbohydrates Pre-Stage & $\begin{array}{l}\text { Grapes, Orange Juice, Jaffa cakes, Dark Chocolate, Wine gums, Jelly Babies, Haribo, Skittles, Honey, Jam, } \\
\text { Jelly, Syrups, Rice cakes, Dextrose, Glucose }\end{array}$ \\
\hline Carbohydrate Sources & $\begin{array}{l}\text { White Potatoes, Sweet Potatoes, Buckwheat, Rice, Oats, Rice Cakes, Marmite (Yeast Extract), Baby Food, } \\
\text { Salted Crisps, Cookies }\end{array}$ \\
\hline Protein and Fat Sources & Almonds, Peanut butter, Cashew butter, Poached Eggs, Steak, Chicken, Turkey, Fry up \\
\hline Alcohol & Brandy, Whisky, Vodka Red/White Wine \\
\hline & Pre-Stage carbohydrates are consumed in the 30 to 60 min period prior to competitors taking the stage to compete.
\end{tabular}

Pre-Stage carbohydrates are consumed in the 30 to $60 \mathrm{~min}$ period prior to competitors taking the stage to compete. 
Table 6. Indicative quotes about competition day strategies amongst British natural bodybuilders.

\begin{tabular}{|c|c|c|}
\hline Strategy & Counts of Qualitative Text & Indicative Quotes \\
\hline Pre-stage Carb. & 55 & $\begin{array}{l}\text { "back stage } 20 \text { mins before stage-skittles/ sugary sweets, } 10 \text { mins before stage pump up", "20 mins before } \\
\text { stage-sugar fix", "Follow regular diet, eat sweets before going on stage", "10 mins before stage } 20 \mathrm{~g} \text { dark } \\
\text { chocolate" "Haribo while pumping up back stage" }\end{array}$ \\
\hline Higher Carb. & 25 & $\begin{array}{l}\text { "rice cakes on honey", "I eat } 100 \mathrm{~g} \text { of chocolate on competition day, sweet potatoes, buckwheat and rice } \\
\text { cakes", "I eat rice cakes and peanut butter jam every } 2 \text { h before judge", "high carb every } 2 \text { h", "not really } \\
\text { loading but large preserve. mainly sweet potato" }\end{array}$ \\
\hline Water Restriction & 11 & $\begin{array}{l}\text { "Minimum water on comp day", "Water only to quench thirst", "Sip water only", "Just sipped water as } \\
\text { needed" "Nil water", "Water cut } 6 \text { p.m. day before comp, then sips with food only" *Water depleting?* } \\
\text { "minimum on Sunday", "I limit my intake to around } 500 \text { mL pre-judging thereafter I had a litre for the } \\
\text { evening for the show" }\end{array}$ \\
\hline Fibre Restriction & 10 & $\begin{array}{l}\text { "My fibre intake is really low on contest day to stop bloating", "minimal veg, easily digestible food", "No } \\
\text { fibrous veg", "Dropped veggies } 24 \text { hre show", "Minimal fibre" "Removal of green veg and oats" }\end{array}$ \\
\hline Comp. Day Alcohol & 15 & $\begin{array}{l}\text { "Before going on stage I will have rice cakes, a few sweets and a glass of wine", "Whilst pumping up, I } \\
\text { will sugar load my system and may have a sip of whisky", "minimum carbs and a whisky before stage", } \\
\text { "Pre stage: red wine + Haribo/Dark Chocolate", "Pre-evening show I have a few sips of red wine" }\end{array}$ \\
\hline High Protein and Fats & 8 & $\begin{array}{l}\text { "Breakfast-fats + protein (eggs +bacon)", "Small amount of steak + rice cakes throughout the day", } \\
\text { "Steak and } 2 \text { eggs for breakfast then just graze during the day on rice cakes and honey", "Healthy fats and } \\
\text { chicken for all meals on competition day", "Fry up for breakfast (sodium + fat)" }\end{array}$ \\
\hline Sodium Loading & 12 & $\begin{array}{l}\text { "I had about } 1500 \mathrm{mg} \text { sodium about an hour before going on stage", "Immediately before stage - salt + } \\
\text { grapes", " } 1 \text { tsp salt prior to stage", "Upped salt on all meals", *use of sodium or salt foods?* "3 g in oats", } \\
\text { "Salty crisps and dark chocolate } 30 \text { to } 40 \text { min before the stage". }\end{array}$ \\
\hline Regular Diet or Other & 17 & $\begin{array}{l}\text { "Regular diet this time", "follow regular prep, add in extra grapes } 20 \text { min before stage", "no plan", } \\
\text { "Followed regular diet mainly, add extra fat at breakfast for energy", "foods low to prevent bloating", } \\
\text { "Nitrix oxide prior to stage" }\end{array}$ \\
\hline
\end{tabular}




\section{Discussion}

This study aimed to identify peaking strategies utilised by competitive natural bodybuilders. Analysis of the data indicated that $93.8 \%$ of competitors were engaged in peaking, with $\mathrm{CHO}$ and water manipulation being the most prevalent peak week strategies. Carbohydrate manipulation strategies were similar to the strategies described by Balon et al. [9] and Aceto [11]. Mega dosing with VITC and sodium manipulation was also utilised during peak week. Contest day nutrition focused on the consumption of high GI CHO, low fibre intake, and, in some cases, was combined with water restriction and alcohol consumption. These findings are in agreement with Mitchell et al. [8] and Alwan et al. [14] who reported a similar focus on $\mathrm{CHO}$, water, and sodium manipulation during peak week amongst bodybuilders and physique competitors. These findings also reflect the deviation from the regular diet noted by Spendlove et al. [7] amongst bodybuilders in the weeks prior to competition. To our knowledge, this is the first study to attempt to quantify the prevalence of peaking strategies amongst natural bodybuilders. This investigation may, therefore, provide a useful starting point for researchers to identify which peaking strategies warrant further investigation. This study also provides additional qualitative comments on how these peaking strategies are employed.

\subsection{Peak Week}

\subsubsection{Carbohydrate Manipulation}

Carbohydrate manipulation strategies followed a similar pattern to classic $\mathrm{CHOL}$, with three days of restriction, followed by three days of CHOL $[9,17]$. Although competitors did not indicate if they altered their exercise routine during the restriction phase, bodybuilders are known to employ high volume resistance training during this period [8]. The addition of exercise alongside $\mathrm{CHO}$ restriction aims to deplete muscle glycogen, as skeletal muscle lacks glucose-6-phosphotase and therefore cannot contribute to maintaining blood glucose [18]. Furthermore, $\mathrm{CHOL}$ following $\mathrm{CHO}$ depletion may result in greater glycogen synthesis activity, enhanced glucose transport, and increased muscle glycogen supercompensation (MGS) [19]. Moreover, studies in animal models indicate greater upregulation of glycogen synthase and glucose transporter type 4 mRNA, following glycogen depletion; while depleted muscle tissue has increased insulin sensitivity over $48 \mathrm{~h}$ dependent on the initial glycogen content [20-22]. Energy intake is inevitably reduced as a consequence of $\mathrm{CHO}$ restriction. It may therefore be prudent for bodybuilders to increase their fibre and protein intake during this phase as a way of compensating for the loss of energy and the additional satiating effect associated with these nutrients [23].

Carbohydrate intakes of 8 to $10.5 \mathrm{~g} / \mathrm{kg} \mathrm{BW}$ per day during CHOL have been demonstrated to produce MGS [18,24]. This equates to a CHO intake 600 to $785.5 \mathrm{~g}$, or 1800 to $2362.5 \mathrm{~g}$ over three days for a $75 \mathrm{~kg}$ bodybuilder. Interestingly, three competitors who quantified their CHOL regime achieved an intake greater than or equivalent to these levels. While bodybuilders may wish to take a more conservative approach to CHOL to prevent "spilling over" (too much $\mathrm{CHO}$ is thought to result in a watery looking physique) [11,12]; lower CHO intake may be inadequate to achieve MGS. It is worth mentioning that traditional $\mathrm{CHOL}$ regimes may not perfectly translate from endurance sport to bodybuilding, e.g., marathon runners are not concerned with CHOL's effect on physical appearance. Conversely extending exercise output is not the goal of a competitive bodybuilder; rather it is full, dry looking muscles. High GI CHO was prioritised at the start of $\mathrm{CHOL}$, before competitors reported moving onto lower GI sources. Carbohydrate loading strategies varied, although, "front-loading", where most of the $\mathrm{CHO}$ was consumed initially, was the most prevalent. This front-loading and the initial use of high GI CHO reflect the notion that glycogen synthesis and storage may be greater in the initial hours following glycogen depletion [20-22]. Front-loading may also suggest a pragmatic approach as bodybuilders seek to reduce $\mathrm{CHO}$ intake closer to competition to reduce unnecessary gastrointestinal or psychological stress associated with peaking [8]. 
Modified, and single day CHOL combined with high intensity sprint exercise, has also been demonstrated to be effective at producing MGS $[25,26]$. One-day protocols could be utilised by bodybuilders and their practicality requires consideration. However, the bodybuilder's sole goal during peak week is not MGS as multiple variables of the diet and training are manipulated simultaneously. Bodybuilders are aiming to enhance the appearance of muscle size that is thought to be achieved from MGS, while also reducing subcutaneous water, which enhances the appearance of definition. Longer peaking strategies provide bodybuilders with time to adjust their strategies depending on their day to day appearance. Furthermore, conventional bodybuilding wisdom advocates two to three days of rest prior to competition [11]. Bodybuilders close to competition may therefore perceive the high intensity sprint exercise employed alongside single day CHOL negatively, although if timed correctly, a single bout of sprint exercise is unlikely to result in delayed onset muscle soreness, or loss of isometric capacity. Single day plans would also reduce the interruption to regular training and pre-contest diet seen when weeklong peaking plans are employed. This may allow the competitor to lose more body fat during this time saved in preparation for competition. Single day plans may therefore represent a viable less stressful alternative to the classical approaches currently employed. Finally, loading strategies should consider the athlete's prior dietary approach and low $\mathrm{CHO}$, high fat diets have been demonstrated to decrease both insulin receptor and glucose transporter type 4 mRNA expression [27]. Despite these findings, CHOL when employed following acute fat adaptation still results in MGS [28], although the effect this approach has on the athlete's physical appearance is unknown.

\subsubsection{Water, Electrolytes, and Vitamin C}

Bodybuilders manipulate water during peak with the goal of facilitating MGS and removing superfluous subcutaneous water. Water manipulation strategies paralleled $\mathrm{CHO}$ manipulation, with high initial intakes followed by a gradual reduction approaching competition day. Previously, Balon et al. [9] and Reale et al. [29] noted that between 2.3 to $7.8 \mathrm{~mL}$ of water is stored per g/glycogen. This would equate to a requirement of 1000 to $3600 \mathrm{~mL}$ of water in a $75 \mathrm{~kg}$ bodybuilder with a CHO store of $462 \mathrm{~g}$. When the bodybuilders' habitual water requirements are considered alongside CHOL, the consumption of additional water to facilitate MGS may be merited. A number of competitors reported consuming between 8 to $12 \mathrm{~L}$ of water per day $(106.6$ to $160 \mathrm{~mL} / \mathrm{kg}$ of bodyweight, $75 \mathrm{~kg}$ bodybuilder) during the loading phase, likely meeting their habitual and CHOL water requirements. Moreover, excessive water consumption causes polyuria, and bodybuilders seek to exploit this diuretic effect, prior to imposing water restriction with the aim of removing any superfluous water [29,30]. Bodybuilders, however, should be mindful that skeletal muscle is largely water, and dehydration may negatively affect their appearance, where muscles could potentially end up "flat" looking, lacking in volume or size [31]. Water manipulation combined with MGS may offer some protection against going "flat", as muscle glycogen is exclusive for skeletal muscle metabolism. Water bound to glycogen would be retained intracellularly provided the bodybuilder refrained from exercise, although extracellular water may still be lost, negatively affecting appearance. Researchers should however, be mindful that peaking strategies might run counter to traditional sports nutrition practice, and bodybuilders will actively seek to dehydrate themselves to obtain a desired "look" at the expense of metrics, like aerobic or anaerobic performance. The success of peaking strategies should therefore be judged on real-world aspects, such as the bodybuilder's competition outcome, physical appearance and performance relative to other competitors, and past performances.

Bodybuilders also attempt to remove subcutaneous water via sodium loading and restriction, while it's worth noting that peak week diets are high in potassium rich foods, e.g., bananas, sweet, and white potatoes. Potassium and sodium are intracellular and extracellular cations, both of which maintain: cellular bioenergetics, integrity, and fluid balance via gated pumps [32]. Moreover, the renal system regulates fluid balance and osmotic pressure by excreting or retaining sodium and potassium depending on their relative concentrations [33]. Exercise scientists have long been aware that the 
addition of electrolytes to water is effective at enhancing hydration [34], while the depletion of these electrolytes results in a loss of fluid, and a reduction in both blood pressure and plasma volume [29]. Manipulation of these electrolytes could therefore potentially alter fluid balance and enhance a bodybuilder's appearance. It was not clear in the present investigation if sodium loading or restricting was the preferred method amongst competitors, although, the "Aceto" peaking method recommends restricting sodium three to four days prior to competition [11]. It is worth noting though that sodium is required as a cotransporter for the uptake of glucose within the small intestine via sodium glucose linked transporter 1 [35]. Restriction of sodium three to four days prior to competition may therefore affect the efficacy of CHOL and the subsequent MGS. A lack of consensus amongst competitors on electrolyte manipulation may also reflect the complexity of adding this additional variable to peaking plans, the outcome of which may be difficult to predict alongside $\mathrm{CHO}$ and water manipulation.

Finally, bodybuilders reported mega dosing with VITC three to four days prior to competition during the water-loading phase. High VITC consumption is known to stimulate diuresis and bodybuilders use VITC in an attempt to remove excess (subcutaneous) water [36,37]. Mega dosing with VITC may cause gastrointestinal issues, while chronic dosing may cause acidification of the urine, and increasing the risk of urate renal stones [38]. Ascorbic acid and urine excretion increases significantly with dosages of VITC over $200 \mathrm{mg}$ [39]; it is therefore plausible that bodybuilders may be able to obtain the same diuretic effect with lower dosages than those reported in the current investigation [39]. Furthermore, employing the diuretic effect of VITC during CHOL and water loading may reduce the efficacy of MGS. Vitamin C loading may therefore be better utilised once the initial CHOL regime is complete to remove subcutaneous water. The consumption of high amounts of herbal tea and protein were other strategies utilised by competitors in an attempt to remove excess water. Such strategies may have some merit as high protein diets are known to increase urea production and glomerular filtration rate both acutely and chronically [40].

\subsection{Competition Day Strategies}

Although competitors reported returning to their regular diet for the competition day following peak week, many of these bodybuilders also reported using an additional competition day strategy, e.g., regular diet and the consumption of high GI CHO pre-stage. The consumption of high GI CHO prior to taking to the competition stage was the most popular competition day strategy. On the competitive stage, bodybuilders are required to perform sustained isometric contractions via mandatory poses for five to $20 \mathrm{~min}$. These isometric contractions are likely to have a high glucose demand and the intake of additional CHO pre-stage seems sensible [41]. Moreover, bodybuilders typically "pump up" (increase the volume of blood concentrated in a muscle by exercising and ergo briefly increasing the size of the muscle) 30 to $60 \mathrm{~min}$ before competing by performing high repetition resistance training [10,12]. Competitors consume $\mathrm{CHO}$ alongside the pump up with belief that it may enhance the muscle pump achieved through cellular swelling [42]. This approach may have some merit amongst competitors with depleted muscle glycogen; however, in competitors practicing $\mathrm{CHOL}$, the additional CHO likely contributes to blood glucose. Some competitors also sodium loaded during the pump up phase, presumably with the same goal in mind. Acute sodium loading is known to increase blood pressure so there may be some rationale for this approach [43]. The persistence of high $\mathrm{CHO}$ diets from peak week also reflects the notion that competitors seek to consolidate the fine tuning achieved during peak week as competitors noted the effect $\mathrm{CHO}$ had on their muscle size. The bodybuilders' competition day requirements are unknown, although this higher $\mathrm{CHO}$ intake is consistent with recommendations for bodybuilding training ( 4 to $7 \mathrm{~g} / \mathrm{kg} \mathrm{BW)} \mathrm{[44].} \mathrm{Interestingly,} \mathrm{some} \mathrm{competitors} \mathrm{consumed} \mathrm{alcohol}$ on competition day. Bodybuilders routinely exclude alcohol from their regular weight loss diet, although it's use as a competition day diuretic is reported in lay literature $[3,11,45]$. Bodybuilders may also be using alcohol for psychological reasons. Bodybuilders compete in minimal clothing in front of audiences and judges; it is possible that some competitors consume alcohol to reduce the stress of competition. 
Fibre restriction via the removal of fibrous vegetables was also prevalent on competition day, as competitors sought to prevent bloating, and maintain a flat waist. Fibre is noted for its ability to increase water retention, and its restriction is recommended for athletes seeking to make weight [29]. Fibre fermentation by the gut microbiota produces short chain fatty acids, which are known to aid sodium and fluid absorption [46]. Reducing fibre intake may therefore be a viable means of achieving the above-mentioned goal. Finally, some competitors utilised high protein and fat meals on the morning of their competition. Some competitors noted utilising a "Fry up", a meal consisting of processed meats, eggs, and fried vegetables as a contest day strategy, while grazing on combinations of rice cakes, preserves, peanut butter, and red and white meat was also reported. These additional fats on competition day likely provide bodybuilders with a valuable source of energy. Although bodybuilders should be cautious about food items they may have previously excluded, particularly those high in sodium, as the effect on their appearance may be difficult to predict when other competition day strategies are also employed.

\subsection{Practical Implications, Safety, and Limitations}

Bodybuilders and coaches should consider peaking strategies with caution. They should be mindful that peaking can be stressful, risky, and may negatively affect a competitor's appearance $[6,8]$. This manuscript should not be considered a guide to peaking; it merely attempts to describe current practices and the plausible mechanisms of action. The strategies reported in the present investigation may also not reflect the most effective strategies to enhance a competitor's aesthetics. Indeed, not all competitors surveyed reported employing a peaking strategy and it is possible that other strategies exist and may be more prevalent in different parts of the world. For example, British natural bodybuilders are known to place a greater emphasis on adherence to the World Anti-Doping Agency code than their American counterparts [47]. This difference in what constitutes "natural" or drug-free may result in differences in dieting and peaking strategies across the Atlantic. Additionally, in non-drug tested bodybuilding, competitors' may make use of pharmaceutical diuretics and anabolic steroids, without medical supervision; further implications of androgenic steroid use are potential water retention [48]. Pharmaceutical diuretics use alongside water and electrolyte manipulation presents an additional danger and professional bodybuilders have died following complications associated with their use $[10,12]$. The use of diuretics and other performance enhancing compounds amongst non-tested bodybuilders may result in athletes taking a different approach to peak week [14]. Moreover, hyponatraemia has been observed in natural athletes over consuming water without the addition of electrolytes (i.e., plain water), and, in the case of those attempting to make weight via diuresis, deaths have occurred [49-51].

The present investigation is not without limitations. Although some athletes provided qualitative data to accompany the quantitative data collection, this data was often provided as short statements rather than detailed accounts. As a result, the exact nature of many of the plans followed could not be quantified. The qualitative data, however, provides useful context on how these plans compare to established strategies [11]. Readers should also be mindful that the data from female competitors reflects athletes competing in different classes (athletic, figure, and bodybuilding). Different physique classes place different expectations on their athletes, which likely influence peaking practices. This fact meant no comparison in peaking methods was made between the male and female cohort. Despite these limitations, the present investigation reported a high prevalence of peaking strategies amongst British natural bodybuilders. Researchers should be mindful of the real-world practices of bodybuilders and seek to understand these strategies. These peaking strategies were ostensibly classic CHOL combined with water manipulation [11,12]. It is possible that experienced bodybuilders can enhance their appearance through peaking, while those considering peaking would be best advised to trial strategies in advance of the competition. Finally, bodybuilders and coaches should be mindful of bodybuilding lore stating that peaking is only likely to be effective if the athlete is suitably conditioned [11]. 


\section{Conclusions}

Peaking and competition day strategies amongst British natural bodybuilders are common. Carbohydrate and water manipulation were the most frequently employed strategies in the present investigation, while electrolyte manipulation was utilised to lesser extent. Moreover, although a small percentage of competitors opted to follow their regular diet during peak week, many of these competitors still employ a competition day strategy. The efficacy of these strategies to improve contest day performance is unknown, however, the persistence amongst bodybuilders suggests peaking strategies may have some merit. The subjective nature of competitive bodybuilding however, makes this last point difficult to quantify. The fact that peaking is so prevalent amongst bodybuilder may make cautioning peaking unrealistic, and nutritionists and coaches should attempt to understand these strategies to better advice competitors. This is the first manuscript that attempts to document and describe peaking practices utilised by competitive natural bodybuilders. Its findings are likely to be of interest to coaches and athletes involved in bodybuilding. Future work should concentrate on the metabolic requirements of competition day bodybuilding to better prepare athletes for their time on stage. Data observing larger numbers of competitors from each of the different classes would add to the present analysis. Finally, more qualitative research is required to better understand the role peaking plays in bodybuilding culture.

Supplementary Materials: The following are available online at http:/ wwww.mdpi.com/2075-4663/6/4/126/s1, Supplementary Materials S1, Dietary assessment questionnaire used to carry out this research.

Author Contributions: A.J.C. conceived the study. A.J.C. and T.N.S. participated in the design of the study. A.J.C. carried out the data collection and analysis. A.J.C. and T.N.S. drafted the manuscript, corrected and edited the paper. All authors approved the final manuscript.

Funding: This research received no external funding.

Acknowledgments: The authors would like to thank the participants for providing their time and effort to complete this study as well as the British Natural Bodybuilding Federation.

Conflicts of Interest: The authors declare no conflict of interest.

\section{References}

1. Liokaftos, D. A Genealogy of Male Bodybuilding: From Classical to Freaky; Routledge, Taylor and Francis Group: New York, NY, USA, 2017.

2. Pardue, A.; Trexler, E.T.; Sprod, L.K. Case study: Unfavorable but transient physiological changes during contest preparation in a drug-free male bodybuilder. Int. J. Sport Nutr. Exerc. Metab. 2017, 27, 550-559. [CrossRef] [PubMed]

3. Chappell, A.J.; Simper, T.; Barker, M.E. Nutritional strategies of high level natural bodybuilders during competition preparation. J. Int. Soc. Sports Nutr. 2018, 15, 4. [CrossRef] [PubMed]

4. Mitchell, L.; Slater, G.; Hackett, D.; Johnson, N.; O'connor, H. Physiological implications of preparing for a natural male bodybuilding competition. Eur. J. Sport Sci. 2018, 18, 619-629. [CrossRef] [PubMed]

5. Tinsley, G.M.; Trexler, E.T.; Smith-Ryan, A.; Paoli, A.; Graybeal, A.; Campbell, B.; Schoenfeld, B. Changes in body composition and neuromuscular performance through preparation, 2 competitions, and a recovery period in an experienced female physique athlete. J. Strength Cond. Res. 2018. [CrossRef] [PubMed]

6. Probert, A.; Palmer, F.; Leberman, S. The Fine Line: An insight into 'risky' practices of male and female competitive bodybuilders. Ann. Leis. Res. 2007, 10, 272-290. [CrossRef]

7. Spendlove, J.; Mitchell, L.; Gifford, J.; Hackett, D.; Slater, G.; Cobley, S.; O'Connor, H. Dietary intake of competitive bodybuilders. Sports Med. 2015, 45, 1041-1063. [CrossRef] [PubMed]

8. Mitchell, L.; Hackett, D.; Gifford, J.; Estermann, F.; O'Connor, H. Do bodybuilders use evidence-based nutrition strategies to manipulate physique? Sports 2017, 5, 76. [CrossRef] [PubMed]

9. Balon, T.W.; Horowitz, J.F.; Fitzsimmons, K.M. Effects of carbohydrate loading and weight-lifting on muscle girth. Int. J. Sport Nutr. 1992, 2, 328-334. [CrossRef] [PubMed]

10. Schwarzenegger, A.; Dobbins, B. The New Encyclopaedia of Modern Bodybuilding; Simon \& Schuster: New York, NY, USA, 1999. 
11. Aceto, C. Championship Bodybuilding; Morris Publishing: Kearney, KS, USA, 2001.

12. Kennedy, R. Encyclopaedia of Bodybuilding: The Complete A-Z Book on Muscle Building; Robert Kennedy Publishing: Mississauga, ON, Canada, 2008.

13. Della Guardia, L.; Cavallaro, M.; Cena, H. The risks of self-made diets: the case of an amateur bodybuilder. J. Int. Soc. Sports Nutr. 2015, 12, 16. [CrossRef] [PubMed]

14. Alwan, N.; Davies, I.; Moss, S.; Morton, J.; McVeigh, J.; Enright, K. Novel insights into methods practised among female physique athletes to acquire optimal body composition. Int. J. Sports Nutr. Exerc. Metab. 2018, 28, S1-S11.

15. British Natural Bodybuilding Federation. Available online: http://www.bnbf.co.uk/banned-substances (accessed on 28 August 2018).

16. World Anti Doping Agency. Available online: https://www.wada-ama.org/en/prohibited-list (accessed on 28 August 2018).

17. Bergstrom, J.; Hermansen, L.; Hultman, E.; Saltin, B. Diet, muscle glycogen and physical performance. Acta Physiol. Scand. 1967, 71, 140-150. [CrossRef] [PubMed]

18. Goforth, H.W., Jr.; Arnall, D.A.; Bennett, B.L.; Law, P.G. Persistence of supercompensated muscle glycogen in trained subjects after carbohydrate loading. J. Appl. Physiol. 1997, 82, 342-347. [CrossRef] [PubMed]

19. Sedlock, D.A. The latest on carbohydrate loading: A practical approach. Curr. Sports Med. Rep. 2008, 7, 209-213. [CrossRef] [PubMed]

20. Kuo, C.H.; Browning, K.S.; Ivy, J.L. Regulation of GLUT4 protein expression and glycogen storage after prolonged exercise. Acta Physiol. Scand. 1999, 165, 193-201. [CrossRef] [PubMed]

21. Lai, Y.C.; Zarrinpashneh, E.; Jensen, J. Additive effect of contraction and insulin on glucose uptake and glycogen synthase in muscle with different glycogen contents. J. Appl. Physiol. 2010, 108, 1106-1115. [CrossRef] [PubMed]

22. Alghannam, A.F.; Gonzalez, J.T.; Betts, J.A. Restoration of muscle glycogen and functional capacity: Role of post-exercise carbohydrate and protein co-ingestion. Nutrients 2018, 10, 253. [CrossRef] [PubMed]

23. Sharafi, M.; Alamdari, N.; Wilson, M.; Leidy, H.; Glynn, E. Effect of a high-protein, high-fiber beverage preload on subjective appetite ratings and subsequent ad libitum energy intake in overweight men and women: A randomized, double-blind placebo-controlled, crossover study. Curr. Dev. Nutr. 2018, 2. [CrossRef] [PubMed]

24. Burke, L.M.; Hawley, J.A.; Schabort, E.J.; St Clair Gibson, A.; Mujika, I.; Noakes, T.D. Carbohydrate loading failed to improve 100-km cycling performance in a placebo-controlled trial. J. Appl. Physiol. 2000, 88, 1284-1290. [CrossRef] [PubMed]

25. Bussau, V.A.; Fairchild, T.J.; Rao, A.; Steele, P.; Fournier, P.A. Carbohydrate loading in human muscle: An improved 1 day protocol. Eur. J. Appl. Physiol. 2002, 87, 290-295. [CrossRef] [PubMed]

26. Fairchild, T.J.; Fletcher, S.; Steele, P.; Goodman, C.; Dawson, B.; Fournier, P.A. Rapid carbohydrate loading after a short bout of near maximal-intensity exercise. Med. Sci. Sports Exerc. 2002, 34, 980-986. [CrossRef] [PubMed]

27. Lambert, E.V.; Hawley, J.A.; Goedecke, J.; Noakes, T.D.; Dennis, S.C. Nutritional strategies for promoting fat utilization and delaying the onset of fatigue during prolonged exercise. J. Sports Sci. 1997, 15, 315-324. [CrossRef] [PubMed]

28. Burke, L.M.; Angus, D.J.; Cox, G.R.; Cummings, N.K.; Febbraio, M.A.; Gawthorn, K.; Hawley, J.A.; Minehan, M.; Martin, D.T.; Hargreaves, M. Effect of fat adaptation and carbohydrate restoration on metabolism and performance during prolonged cycling. J. Appl. Physiol. 2000, 89, 2413-2421. [CrossRef] [PubMed]

29. Reale, R.; Slater, G.; Burke, L.M. Acute-weight-loss strategies for combat sports and applications to olympic success. Int. J. Sports Physiol. Perform. 2017, 12, 142-151. [CrossRef] [PubMed]

30. Shirreffs, S.M.; Armstrong, L.E.; Cheuvront, S.N. Fluid and electrolyte needs for preparation and recovery from training and competition. J. Sports Sci. 2004, 22, 57-63. [CrossRef] [PubMed]

31. Helms, E.R.; Aragon, A.A.; Fitschen, P.J. Evidence-based recommendations for natural bodybuilding contest preparation: Nutrition and supplementation. J. Int. Soc. Sports Nutr. 2014, 11, 20. [CrossRef] [PubMed]

32. Dibrova, D.V.; Galperin, M.Y.; Koonin, E.V.; Mulkidjanian, A.Y. Ancient systems of sodium/potassium homeostasis as predecessors of membrane bioenergetics. Biochemistry (Moscow) 2015, 80, 495-516. [CrossRef] [PubMed] 
33. O'Donnell, M.; Mente, A.; Rangarajan, S.; McQueen, M.J.; Wang, X.; Liu, L.; Yan, H.; Lee, S.F.; Mony, P.; Devanath, A.; et al. Urinary sodium and potassium excretion, mortality, and cardiovascular events. N. Engl. J. Med. 2014, 371, 612-623. [CrossRef] [PubMed]

34. Hamilton, K.L. Robert K. Crane--Na ${ }^{+}$-glucose cotransporter to cure? Front. Physiol. 2013, 4, 53. [CrossRef] [PubMed]

35. Sharp, R.L. Role of sodium in fluid homeostasis with exercise. J. Am. Coll. Nutr. 2006, 25, 231 S-239S. [CrossRef] [PubMed]

36. Abbasy, M.A. The diuretic action of vitamin C. Biochem. J. 1937, 31, 339-342. [CrossRef] [PubMed]

37. Michels, A.J.; Frei, B. Myths, artifacts, and fatal flaws: Identifying limitations and opportunities in vitamin C research. Nutrients 2013, 5, 5161-5192. [CrossRef] [PubMed]

38. Ferraro, P.M.; Curhan, G.C.; Gambaro, G.; Taylor, E.N. Total, dietary, and supplemental vitamin C intake and risk of incident kidney stones. Am. J. Kidney Dis. 2016, 67, 400-407. [CrossRef] [PubMed]

39. Levine, M.; Conry-Cantilena, C.; Wang, Y.; Welch, R.W.; Washko, P.W.; Dhariwal, K.R.; Park, J.B.; Lazarev, A.; Graumlich, J.F.; King, J.; Cantilena, L.R. Vitamin C pharmacokinetics in healthy volunteers: Evidence for a recommended dietary allowance. Proc. Natl. Acad. Sci. USA 1996, 93, 3704-3709. [CrossRef] [PubMed]

40. Cuenca-Sanchez, M.; Navas-Carrillo, D.; Orenes-Pinero, E. Controversies surrounding high-protein diet intake: satiating effect and kidney and bone health. Adv. Nutr. 2015, 6, 260-266. [CrossRef] [PubMed]

41. Gollnick, P.D.; Karlsson, J.; Piehl, K.; Saltin, B. Selective glycogen depletion in skeletal muscle fibres of man following sustained contractions. J. Physiol. 1974, 241, 59-67. [CrossRef] [PubMed]

42. Schoenfeld, B.; Contreras, B. the muscle pump: Potential mechanisms and applications for enhancing hypertrophic adaptations. Strength Cond. J. 2014, 36, 21-25. [CrossRef]

43. Stachenfeld, N.S. Acute effects of sodium ingestion on thirst and cardiovascular function. Curr. Sports Med. Rep. 2008, 7, S7-13. [CrossRef] [PubMed]

44. Ron, M.; Susan, S. Nutrition guidelines for strength sports: Sprinting, weightlifting, throwing events, and bodybuilding. In Food, Nutrition and Sports Performance III; Routledge: Abingdon, UK, 2011.

45. Strauss, M.B.; Rosenbaum, J.D.; Nelson, W.P. The effect of alcohol on the renal excretion of water and electrolyte. J. Clin. Investig. 1950, 29, 1053-1058. [CrossRef] [PubMed]

46. Binder, H.J.; Brown, I.; Ramakrishna, B.S.; Young, G.P. Oral rehydration therapy in the second decade of the twenty-first century. Curr. Gastroenterol. Rep. 2014, 16, 376. [CrossRef] [PubMed]

47. Liokaftos, D. Defining and defending drug-free bodybuilding: A current perspective from organisations and their key figures. Int. J. Drug Policy 2018, 60, 47-55. [CrossRef] [PubMed]

48. Gentil, P.; De Lira, C.; Paoli, A.; Dos Santos, J.; Da Silva, R.; Pereira, J.; Da Silva, E.; Magosso, R. Nutrition, pharmacological and training strategies adopted by six bodybuilders: Case report and critical review. Eur. J. Transl. Myol. 2017, 27, 6247. [CrossRef] [PubMed]

49. Roberts, W.O. Keeping sports safe: Physicians should take the lead. Physician Sportsmed. 1998, 26, 25-28. [CrossRef] [PubMed]

50. Thompson, R.A. The last word. Eat. Disord. 2007, 6, 207-210. [CrossRef]

51. Centers for Disease Control and Prevention. Hyperthermia and dehydration related deaths associated with intentional rapid weight loss in three collegiate wrestlers. MMWR Morb. Mortal. Wkly. Rep. 1998, 47, 105-108.

(C) 2018 by the authors. Licensee MDPI, Basel, Switzerland. This article is an open access article distributed under the terms and conditions of the Creative Commons Attribution (CC BY) license (http://creativecommons.org/licenses/by/4.0/). 